\title{
EFEK EKSTRAK ETHANOL DAUN KELOR (MORINGA OLEIFERA) TERHADAP PROTEKSI FUNGSI HATI DAN HISTOPATOLOGI TIKUS PUTIH (RATTUS NORVEGICUS) YANG DIINDUKSI KARBONTETRAKLORIDA (CCL4)
}

\section{EFFECT OF KELOR LEAF ETHANOL EXTRACT (MORINGA OLEIFERA) ON THE PROTECTION OF HEART AND HISTOPATOLOGICAL FUNCTION OF CARBONTETRAKLORIDA (CCL4) INDUCED RATTUS NORVEGICUS}

\author{
Oleh \\ ${ }^{1}$ Siti Hardiyanti Nawir, ${ }^{2}$ Peter Kabo, ${ }^{3}$ Ilhamjaya Pattelongi \\ ${ }^{1}$ Pendidikan Dokter, Universitas Bosowa \\ (Email:hardiyantinawir90@gmail.com) \\ 2Departemen Farmakologi, Fakultas Kedokteran, ${ }^{2}$ Universitas Hasanuddin \\ (Email:peterkabo_fkuh@gmail.com) \\ ${ }^{3}$ Departemen Fisiologi, Fakultas Kedokteran, Universitas Hasanuddin
}

(Email: ilham_pt@yahoo.com)

\begin{abstract}
Abstrak
Kerusakan hati menjadi salah satu penyakit dengan prevalensi yang tinggi khususnya di negara berkembang. Penelitian ini bertujuan untuk melihat adanya efek ekstrak ethanol daun kelor

(Moringa oleifera) terhadap proteksi fungsi hati dan histopatologi tikus putih (Rattus norvegicus) yang diinduksi karbontetraklorida ( $\left.\mathrm{ccl}_{4}\right)$. serta menentukan dosis efektif dari kombinasi tersebut. Penelitian ini dilakukan secara eksperimental laboratorium menggunakan metode eksperimen dengan desain post test only control group pada tikus wistar. Tikus dibagi menjadi 5 kelompok, yaitu kelompok kontrol positif (ekstrak kurkuma), kontrol pembanding ( $\mathrm{NaCMC} \mathrm{1 \% )} \mathrm{dan} 3$ kelompok pemberian ekstrak dengan 3 variasi dosis masing-masing $250 \mathrm{mg} / \mathrm{kgBB}, 500 \mathrm{mg} / \mathrm{kgBB}$ dan $750 \mathrm{mg} / \mathrm{kgBB}$. Dilakukan pengamatan terhadap uji profil kimia darah yang meliputi SGOT dan SGPT serta dilanjutkan dengan uji histopatologi. Hasil menunjukkan bahwa adanya perbedaan perubahan hasil pengukuran darah fungsi hati (SGOT dan SGPT) antar kelompok selama 8 hari. Hasil menunjukkan bahwa adanya perbedaan perubahan hasil pengukuran profil kimia darah antar kelompok selama perlakuan. Berdasarkan hasil uji one way ANOVA pada pengukuran SGOT dan SGPT terdapat hasil tes bermakna $(\mathrm{P}<0,05)$. Hasil uji histopatologi menunjukkan bahwa terdapat perbaikan fungsi dan struktur hati pada kelompok pemberian ekstrak etanol daun kelor. Dapat disimpulkan bahwa ekstrak etanol daun kelor (Moringa oleifera) memiliki kemampuan sebagai hepatoprotektor terhadap fungsi hati pada dosis 750 $\mathrm{mg} / \mathrm{kgBB}$.

Kata Kunci: Daun kelor, Penyakit hati, Karbontetraklorida, histopatologi
\end{abstract}

\section{ABSTRACT}

Liver damage is one of the diseases with high prevalence especially in developing countries. This study aims to see the effect of ethanol extract of Moringa oleifera leaves on liver function protection and histopathology of white rat (Rattus norvegicus) induced by 
carbontetrachloride (CCl4). and determine the effective dose of the combination. This research was conducted experimentally using a laboratory experimental method with a post test only control group design

in wistar rats. Rats were divided into 5 groups, namely the positive control group (curkuma extract), comparative control (NaCMC 1\%) and 3 groups giving extracts with 3 variations of each dose of $250 \mathrm{mg} / \mathrm{kgBB}, 500 \mathrm{mg} / \mathrm{kgBB}$ and $750 \mathrm{mg} / \mathrm{kgBB}$. Observations were made on the blood chemistry profile test which included SGOT and SGPT and continued with histopathological testing. The results showed that there were differences in changes in the results of liver function blood measurements (SGOT and SGPT) between groups for 8 days. The results showed that there were differences in changes in the measurement results of blood chemistry profiles between groups during treatment. Based on the results of the one way ANOVA test on SGOT and SGPT measurements there were significant test results ( $P$ $<0.05)$. The results of histopathological tests showed that there was an improvement in liver function and structure in the group given ethanol extract of kelor leaves. It can be concluded that the ethanol extract of Moringa oleifera leaves has the ability as a hepatoprotector of liver function at a dose of $750 \mathrm{mg} / \mathrm{kgBB}$.

Keywords: Moringa Leaves, Liver Disease, Carbontetrachloride, Histopathology

\section{A. PENDAHULUAN}

Hati merupakan pabrik kimia tubuh, hati memiliki pendarahan ganda, dari arteri hepatika dan vena porta. Fungsi hati sangat banyak dan dikelompokkan menjadi tiga fungsi diantaranya yang berkaitan dengan darah, yang berkaitan dengan makanan dan fungsi yang berkaitan dengan pembuangan 'racun'. (Anita, 2011)

Sebagian masyarakat beranggapan bahwa penyakit hepatitis atau lever disebabkan oleh kerja keras, kurang beristirahat,minum minimal alcohol, makan obat lama dan zat beracun lainnya, sebenarnya anggapan tersebut tidak sepenuhnya benar. Kerja keras memang dapat memperberat fungsi hati, terutama bagi yang sudah positif menderita penyakit tersebut. Saat ini sudah diketahui beberapa jenis hepatitis yaitu hepatitis A,B,C,D,E dan seterusnya. Gangguan ini disebabkan oleh serangan virus pada organ hati, akibatnya struktur jaringan hati menjadi kacau, kerja hatipun otomatis terganggu, serta zat toksik yang masuk kedalam tubuh. (Andrianto, 2011).

Berbagai zat karsinogen juga menyebabkan terbentuknya Reactive Oxygen Species (ROS) yang dapat menyebabkan terjadinya kerusakan sel selama proses metabolismenya, salah satunya yaitu senyawa Karbon tetraklorida (CC14) yang merupakan xenobiotic yang lazim digunakan untuk menginduksi peroksidasi lipid dan 
keracunan. Dalam endoplasmik reticulum hati, $\mathrm{CCl} 4$ dimetabolisme oleh sitokrom p450 2EI (CYP2EI) menjadi radikal bebas triklorometil $(\mathrm{CCl} 3 *)$. Selanjutnya triklorometilperoxi menyebabkan peroksidasi lipid sehingga mengganggu homeostasis $\mathrm{Ca}^{2+}$, dan akhirnya menyebabkan kematian sel. (Ruqiah et al., 2007).Saat ini pengobatan tradisional memang sudah banyak tergantikan oleh pengobatan modern, namun seiring dengan slogan Back to Nature maka ramuan tradisional mulai banyak dilirik kembali. Berbagai penelitian membuktikan meskipun ramuan tradisional biasanya terdiri dari bahan - bahan herbal yang ada disekitar kita, namun tetap harus diperhatikan takaran dan zat yang dikandung. Dengan mempergunakan takaran yang pas dalam ramuan tradisional maka manfaat yang diperoleh menjadi lebih optimal. (Murtie, 2013).

Salah satu tanaman yang
berdasarkan ethnomedicine
terbukti belah
hepatoprotektor adalah daun kelor
(Moringa oleifera) yang telah terbukti
sebagai antioksidan dan mencegah
beberapa penyakit salah satunya

kerusakan hati. Metode penelitian berupa eksperimen dengan post test only control group design pada tikus wistar jantan. Ekstrak daun kelor (Moringa oleifera) memiliki kandungan yang berbeda-beda seperti flavonoid, asam fenolik, karotenoid, polyunsaturated fatty acids (PUFAs), mineral tinggi dan folat yang bersifat antioksidan tinggi dan dapat berfungsi hepatoprotektor pada kerusakan sel hati. (Kumar, 2016)

Penelitian tentang daun kelor di Indonesia masih sedikit terutama sebagai antioksidan yang mampu memperbaiki sel-sel hati atau sebagai hepatoprotektor. Oleh sebab itu penelitian mengenai efek hepatoprotektor ekstrak etanol daun kelor (Moringa oleifera) terhadap fungsi hati dan histopatologi tikus putih (Rattus novergicus) yang diinduksi CC14. (Jannah et al., 2017)

\section{B. METODE PENELITIAN}

\section{Lokasi dan Rancangan penelitian}

Penelitian ini akan dilaksanakan di Fakultas Farmasi Universitas Hasanuddin. Jenis penelitian yang dilakukan adalah eksperimental di laboratorium menggunakan metode post 
test only control group design pada tikus wistar.

\section{Populasi dan sampel}

Populasi pada penelitian ini adalah tikus putih wistar (Rattus novergicus). Pemilihan sampel penelitian menggunakan teknik Simple Random Sampling dengan kriteria hewan coba berusia 8 minggu dengan bobot 150-200 gram, berjenis kelamin jantan, sehat dan tidak terinfeksi. Metode pengumpulan data

Sebelum diberi perlakuan, seluruh hewan uji perlu penyesuaian fisiologi, perilaku dan nutrisi melalui aklimatisasi. Periode aklimatisasi dilakukan selama 2 minggu, menyesuaikan periode aklimatisasi yang dipersyaratkan oleh USDA dalam Guideline Stabilization/Acclimation Times for Research Animals (2011), yaitu minimal selama 7 hari. Dilakukan pengamatan terhadap pemberian ekstrak dan pengambilan sampel darah sebelum perlakuan, setelah pemberian ekstrak, dan setelah pemberian zat karbontetraklorida (CC14). Setelah hari ke 7 , semua hewan coba diterminasi dengan cara cervical dislocation,
Kemudian diambil bagian organ dalam hewan coba untuk dilakukan uji histoptologi anatomi.

\section{Analisis data}

Dari hasil penelitian diperoleh data penelitian yang dikumpulkan kemudian dilakukan analisis statistik menggunakan metode uji ANOVA (Analysis Of Variance) dan dilanjutkan dengan uji post hoct menggunakan uji Tukey untuk melihat perbedaan antar kelompok.

\section{HASIL DAN PEMBAHASAN}

Induksi ekstrak daun kelor (Moringa oleifera) dan Karbon Tetraklorida (CCl4)

Penginduksian Karbon Tetraklorida (CCl4) diberikan sebanyak $1 \mathrm{~mL} / \mathrm{KgBB}$. diinjeksikan secara Intraperitoneal (IP). Setelah penginduksian, pengamatan dilakukan 1x 24 jam. Gambar 1 menunjukkan proses penginduksian karbontetraklorida pada hewan uji tikus. Gambar 2 menunjukkan proses pengambilan darah tikus wistar.

Profil kimia darah SGOT sebelum induksi karbontetraklorida 
Setelah pemberian ekstrak daun kelor, dilakukan pengambilan darah untuk melihat fungsi hati sebelum pemberian karbontetraklorida, setelah pemberian ekstak etanol daun kelor (Moringa oleifera) selama 5 hari kemudian di lakukan pemeriksaan profil kimia darah untuk melihat fungsi hati. Grafik 1 menunjukkan hasil uji profil kimia darah SGOT sebelum dan setelah pemberian karbontetraklorida (CCl4).

\section{Profil kimia darah SGPT setelah}

\section{induksi karbontetraklorida}

Pada hari ke 7 Setelah pemberian ekstrak daun kelor dan karbontetraklorida dilakukan pengambilan darah untuk melihat fungsi hati. Grafik 2 menunjukkan hasil uji profil kimia darah SGPT hewan uji tikus sebelum dan setelah pemberian karbontetraklorida (CCl4).

Berdasarkan hasil penelitian menunjukkan bahwa pemberian ekstrak etanol daun kelor (Moringa oleifera) dengan dosis $250 \mathrm{mg} / \mathrm{kgBB}$ dan 500 $\mathrm{mg} / \mathrm{kgBB}$ kurang optimal dalam memberikan efek hepatoprotektor. Namun, pada kelompok pemberian ekstrak etanol daun kelor (Moringa oleifera) dengan dosis $750 \mathrm{mg} / \mathrm{kgBB}$ dapat memberikan efek hepatoprotektor dengan baik serta dapat mengurangi terjadinya kerusakan hati. Hal ini berdasarkan pada hasil profil kimia darah fungsi hati menunjukkan bahwa kerusakan suatu jaringan sel hati terjadi pada kelompok pemberian ekstrak etanol daun kelor (Moringa oleifera) 750 $\mathrm{mg} / \mathrm{kgBB}$ tingkat kerusakan jaringan sel hati, lebih baik dibandingkan kelompok pemberian NaCMC 1\% dan kelompok lainnya.

Hati merupakan organ yang sangat penting dalam pengaturan homeostasis tubuh meliputi metabolisme, biotransformasi, sintesis, penyimpanan dan imunologi. Sel - sel hati hepatosit mempunyai kemampuan regenerasi yang cepat. Oleh karena itu sampai batas tertentu, hati dapat mempertahankan fungsinya bila terjadi gangguan ringan. Pada gangguan yang lebih berat, terjadi gangguan fungsi yang serius dan akan berakibat fatal. (DEPKES RI., 2007).Tumbuhan obat merupakan segala jenis tumbuhan atau tanaman yang diketahui mempunyai khasiat, baik dalam membantu memelihara kesehatan maupun 
pengobatan suatu penyakit. daun kelor merupakan salah satu tanaman tradisonal yang diketahui memiliki anti oksidan tinggi yang mampu mengobati penyakit hati, salah satunya senyawa flavonoid sebagai salah satu kelompok senyawa fenolik yang banyak terdapat pada jaringan tanaman dapat berperan sebagai antioksidan. Aktivitas antioksidatif flavonoid bersumber pada kemampuan mendonasikan atom hidrogennya atau melalui kemampuannya mengikat logam. Berbagai hasil penelitian menunjukkan bahwa senyawa flavonoid mempunyai aktivitas antioksidan yang beragam pada berbagai jenis sereal, sayuran dan buahbuahan. (Redha, 2010)

Kerusakan organ oleh zat kimia karbontetraklorida (CCl4) mampu merusak hati karena merupakan xenobiotic yang lazim digunakan untuk menginduksi peroksidasi lipid dan keracunan. Dalam endoplasmik reticulum hati, $\mathrm{CCl}$ dimetabolisme oleh sitokrom p450 2EI (CYP2EI) menjadi radikal bebas triklorometil $\left(\mathrm{CCl}^{*}\right)$. Triklorometil dengan oksigen akan membentuk radikal triklorometilperoxi yang dapat menyerang lipid membran endoplasmik reticulum dengan kecepatan yang melebihi radikal bebas triklorometil. Selanjutnya triklorometilperoxi menyebabkan peroksidasi lipid sehingga mengganggu homeostasis $\mathrm{Ca}^{2+}$, dan akhirnya menyebabkan kematian sel (Ruqiah et al., 2010).

Penyusun utama membran sel adalah lipid, protein dan karbohidrat. Lipid yang menyusun membran adalah fosfolipid. Fosfolipid merupakan molekul yang bersifat amfipatik, artinya memiliki daerah hidrofilik dan hidrofobik. Keberadaan dua lapis fosfolipid mengakibatkan membran memiliki permeabilitas selektif, tetapi protein juga ikut menentukan sebagian besar fungsi spesifik membran.Asam lemak penyusun membrane sel, khususnya asam lemak rantai panjang tak jenuh (PUFAs) sangat rentan terhadap radikal bebas. Menurut Jeon $e t$ al. jumlah PUFAs dalam fosfolipid membrane endoplasmik retikulum akan berkurang sebanding dengan jumlah CCl4 yang diinduksi. Pemberian CCl4 dalam dosis tinggi dapat merusak endoplasmik reticulum, mengakumulasi lipid, mengurangi sintesis protein, 
mengacaukan proses oksidasi, menurunkan bobot badan, menyebabkan pembengkakan hati, sehingga bobot hati menjadi bertambah, dan pemberian jangka panjang dapat menyebabkan nekrosis sentrilobular serta degerasi lemak dihati. (Rames et al., 2016). Menelan paling sedikit $5 \mathrm{ml} \mathrm{CCl4}$ telah dilaporkan berakibat fatal. Parah dan kadang-kadang fatal dalam merusak hati dan ginjal mungkin terlihat setelah 1-3 hari (Olson., 2004). kstrak daun kelor (Moringa oleifer) mengandung senyawa kimia flavonoid, benzil isothiosianat dan fenetil isothiosianat yang terbukti mampu menghambat kerusakan hati. Ekstrak daun kelor juga dapat menurunkan aktivitas NF-KB dengan cara menghambat pembentukan ROS sehingga $\mathrm{IKb}$ tidak terfosforilasi dan NF-кB dapat dihambat (Andjani, 2016).

\section{KESIMPULAN DAN SARAN}

Berdasarkan hasil penelitian menunjukkan bahwa ekstrak etanol daun kelor (Moringa oleifera) memiliki kemampuan sebagai hepatoprotektor terhadap fungsi hati. Dosis optimal dari ekstrak etanol daun kelor (Moringa oleifera) yang memiliki aktifitas sebagai hepatoprotektor yaitu pada dosis 750
mg/kgBB. Sebaiknya dilakukan penelitian lebih lanjut mengenai dosis efektif dari ekstrak etanol daun kelor (Moringa oleifera).

\section{DAFTAR PUSTAKA}

Adewale O.B., Adekeye A.O., Akintayo C.O., Onikanni A., \& Sabiu Saheed. (2014). Carbon tetrachloride (CCl4)-induced hepatic damage in experimental Sprague Dawley Rats: Antioxidant potential of Xylopia aethiopica, The Journal of Phytopharmacology 2014; 3(2): 118-123.

Andrianto T.T. (2011). Ampuhnya Herbal Berantas Berbagai Penyakit Berat. Najah.Jogjakarta. hal 9-15.

Andjani ., Hidayat \& S, Sri W. (2016). Efek ekstrak etanol daun kelor (Moringa oleifera) terhadap nuclear factor kappa beta (NF$\mathrm{KB})$ aktif dan apoptosis cell line kanker MCF-7. Majalah Kesehatan FKUB 3: 205.

Anita S., Tej K.B., \& Sharma. (2011). Clinical Biochemistry of Hepatotoxicity, Clinical Toxicology, J Clinic Toxicol S4:001. doi:10.4172/21610495.S4-001, hal 1-19.

Cotran R.S., Kumar V., \& Collin T. (1999). Neoplasia in Robbins Pathologic Basic of Disease, Sixth Edition, Philadelphia: W.B. Saunders Company. 260325. Depkes RI.(2010). Pharmaceutical Care Untuk Penyakit Hati.Jakarta. hal 3-31.

Jannah M. Trihadi D., \& Nasihun T. (2017). The Effect of Moringa 
Oleifera. Lam leaf Extract on $\mathrm{Bcl} 2$ and Bax Expression in Paracetamol - induced Renal Tubular Apoptosis in Rats. Jurnal Unissual. Vol.8 (2) : 6167.

Hermawan A., Nur K.A., Samoko D.D., Putri P., \& Meiyanto E. (2012). Ethanolic Extract of Moringa oleifera Increased Cytotoxic Effect of Doxorubicin on Hela Cancer cells. Journal Natural Remedies; 12(2) : 106-114.

Murtie S. (2013). Kupas Tuntas Pengobatan Tradisional. Trans Idea Publishing.Jogjakarta. hal 19-25.

Noer K., Masfufatun., \& Emilia D.D. (2016). Potensi Ekstrak Daun Kelor (Moringa Oleifera) Sebagai Hepatoprotektor Pada Tikus Putih (Rattus Novergicus) Yang Diinduksi Parasetamol Dosis Toksis. Jurnal "Ilmiah Kedokteran" Volume 5 Nomer 1 Edisi Maret 2016, hal. $58-66$.
Okta H.P., et al. (2018). Pengaruh Pemberian Ekstrak Daun Kelor (Moringa Oleifera) Dosis Bertingkat Pada Gambaran Mikroskopis Hepar Tikus Wistar Yang Dinduksi Formalin, Jurnal Kedokteran Diponegoro, Vol: 7;2 : 11291142.

Olson K.R. (2004). Poisioning and Drug Overdose.5th ed. Boston: Mc Graw Hill Co. 21:517-522.

Ramesh K., Iyyakannu S., \& Young S.K. (2016). "Phytochemicals of Moringa oleifera: a review of their nutritional, therapeutic and industrial significance, Article review, Crossmark. 6:203.

Redha A. (2010). Flavonoid: Struktur, Sifat Antioksidatif Dan Peranannya Dalam Sistem Biologis.,Vol.9;196-202.

Ruqiah G.P.P., et al. (2010). Pengaruh Pemberian Karbon Tetraklorida Terhadap Fungsi Hati Dan Ginjal Tikus. Makara Kesehatan, Vol. 11, no. 1, Juni 2010: 11-16 